\title{
Maailma on säilytettävä lapsenlapsenlapsille
}

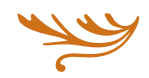

KuULUN SELLAISIIN 1960-luvun idealisteihin, joiden mielestä kaikki on enemmän tai vähemmän poliittista. Kapeasti poliittisen lisäksi myös muut tekomme lasten hankinnasta englannin- tai suomenkielisten artikkelien kirjoittamiseen ovat "poliittisia" valintoja. Näillä valinnoilla on vaikutusta siihen tulevaisuuteen, jota en ehkä itse enää näe. Sanon näin, koska olen 65-vuotias, ja monet ilmastonmuutokseen liittyvistä tendensseistä voivat hyvinkin näkyä vasta muutaman kymmenen vuoden kuluttua.

Toisaalta, vuodenvaihteessa 2013 myrskyt pyyhkivät eri puolilla maailmaa, niin tiuhaan, että on vaikea tietää, kuinka vähän tai paljon aikaa meillä onkaan säilyttää maapallo elinkelpoisena.

On itsestään selvää, että kulutusta on vähennettävä. Nykyisin kulutamme 2,5 kertaa sen, minkä maapallomme tuottaa vuodessa. Kulutamme siis liikaa. Jos haluamme välttää ekokatastrofin, joudumme vähentämään kulutusta. Suuri kysymys on, miten tämä tapahtuu.

\section{TALOUDELLISTEN RESURSSIEN UUSJAKO}

"Degrowth"-liikkeessä mukana olevien ihmisten mukaan taloudellinen kasvu ei ole elämän jatkumisen kannalta enää mahdollista. Kasvun sijaan taloudessa tulisi etsiä vähintään pysähtymistä ja toivottavasti kasvun purkua tai vähenevää kasvua. Jos taloudellinen toimeliaisuus, ja siis luonnon eli maan, veden ja ilman saastuttaminen ei vähene, on edessä hallitsematon ekokatastrofi.

Kasvun vähentämistä vaativien idealistien toinen tärkeä vaatimus on taloudesta syntyvän hyvän tasaisempi jakaminen. Toisin sanoen hyvinvoivan lännen tulisi kuluttaa vähemmän, mutta köyhän etelän nykyistä enemmän. Kasvun vähentäminen tarkoittaisi myös taloudellisten resurssien uusjakoa sekä maailman mittakaavassa että paikallisesti, myös Suomessa. Kyseessä on siis eräänlainen maailmanlaajuinen keynesiläisyyden muunnos, globaali hyvinvointivaltio. Erona Keynesin ajattelun ja degrowthin välillä on toki se, että aikaisemmassa uskottiin, että taloudellinen kasvu voi jatkua ja jatkua.

Jarna Pasanen ja Marko Ulvila ovat keränneet teokseensa Vihreä uusjako (2010) tietoa kulutuksen ja varallisuuden suhteesta. Tutkimuksen sanoma on niin sanotun vihreän kulutuksen kannalta huono. Ainoa asia, mikä vähentää kulutusta, on köyhyys tai pienet tulot.

Vihreät kuluttajat, kuten jätteiden lajittelijat, ekosähkön ja kasvisravinnon käyttäjät, kuluttavat sähköä harkitummin, lentävät vähemmän ja välttävät ylipäänsä muita runsaasti öljyä vaativia tekoja. Hyvät teot yhtäällä aiheuttavat huolettomuutta tai suoranaista tuhlausta muualla. Mutta yleisesti ottaen erittäin rikkaat ihmiset kuluttavat monikymmenkertaisesti, ellei jopa monisatakertaisesti sen, mitä varattomat. Vihreimpiä kuluttajia ovat siis köyhät.

Pasanen ja Ulvila uskovat, että Suomessa ekologisesti kestävä kulutus merkitsisi 1970-luvun kulutustasoa. Itse voisin ihan hyvin sellaisessa maailmassa elää - olin tuolloin tyytyväinen, sillä ainakin 1950-lukuun verrattuna elämä oli runsasta. Toisaalta on myös väitetty, että nykyisin Suomessa vain asunnottomat täyttävät ekologisesti kestävän elämäntavan kriteerit eli kuluttavat vain sen verran öljyä ja muita maapallon resursseja, minkä maapallo tuottaa.

Tämä olisi minulle sopiva ihanne, mutta mahdoton toteuttaa. Vähempiä valintoja sen sijaan pyrin koko ajan tekemään. Ekologisiin kulutusvalintoihin ajaa se, että toivoa maailman säilymisestä on pidet- 
tävä yllä. Jos ei tee mitään, ei voi myöskään säilyttää uskoa vaikuttamisen mahdollisuuksiin.

\section{KULUTUSVALINTOJA ARJESSA}

Alun perin olen aloittanut niin sanotun eettisen kulutuksen boikotoimalla Nestléä ja israelilaisia appelsiinejä, eikä kummassakaan ollut oikeastaan kysymys luonnosta, vaan politiikasta.

Nestlé myi äidinmaidonvastiketta Afrikkaan, missä vesi saattoi olla vauvoille vahingoksi. Israelilaisten hedelmien boikotoiminen liittyi Israelin aggressiiviseen politiikkaan palestiinalaisia kohtaan. Molempia boikotteja olen harrastanut (enemmän tai vähemmän intensiivisesti) nykyaikaan saakka. Ne myös omalla tavallaan kertovat ostovalintojen tehokkuudesta. Sekä Nestléllä että israelilaisilla hedelmillä on niin paljon kysyntää, ettei niiden tarvitse politiikkaansa minun ja muiden 1960-luvun idealistien takia muuttaa.

Tärkein vihreä kulutusvalintani on autottomuus. Koska minulla ei ole ajokorttia, ei ole myöskään kiusausta käyttää muuta kuin julkista liikennettä. Asuntoni on yhdelle ihmiselle suhteellisen suuri, yli 80 neliötä. Parhaillaan siinä asuu lisäkseni lukiota käyvä lapsenlapsi ja aikuinen tytärkin melko tiheään; se hieman kompensoi ylileveää asumistani. Olen ollut kiihkeä kierrättäjä ja kompostoija niin kauan kuin muistan. Ruokailussa suosin lähiruokaa, mikä ei läheskään kaikessa ole mahdollista. Lisäksi olen innokas harrastelijaviljelijä. Aiemmin pidin stadissa viljelypalstaa, nykyisin harrastan puutarhaa Kiskossa tyttären pihalla.

Kerään myös innokkaasti villivihanneksia, joita ennen kutsuttiin rikkaruohoiksi. Termin keksijä, Vivi-Ann Sjögren sanoi, että "ne ovat ekologisinta mahdollista ruokaa, koska ne ovat itse paikkansa valinneet ja tuottavat hyvin siinä, missä ovat".

Vaikka kerään satunnaisesti villivihanneksia ja viljelen ilman keinolannoitetta, en tee läheskään kaikkea syömisen eteen. Niin sanottu kunnollinen ilmastonystävä pystyisi muuhunkin. Syön kyllä mielelläni eläinten sisäelimiä ja sellaista kalaa, jota meillä pidetään roskakalana, mutta pidän myös juustoista ja viinistä. Sisäelimet ja roskakalan lasken ilmastonystävän ruokalistalle. Argentiinalainen liha tai norja- laisen lohi eivät sinne kuulu. Teokseen Kausiruokaa herkuttelijoille ja ilmastonystäville on laskettu erilaisten ruoka-aineiden hiilijalanjäljet. Olen napannut siitä joitakin ideoita keittiööni.

\section{LISÄÄ JULKISTA KONTROLLIA}

Kuluttamisen vähentämisen lisäksi olisi järkevää käyttää aineettomia palveluita, kuten julkisia kulttuuri- ja hoivapalveluita sekä vanhusten hoivaa, lastenhoitoa ja koulutusta. Toki näihinkin palveluihin ympätään lisääntyvässä määrin tavaraa (tietokoneita, robotteja ja muita kapineita), ja kaikkinainen keskittäminen merkitsee välimatkan ja autoilun lisääntymistä. Käytännössä palveluissa kuitenkin kulutetaan materiaa suhteellisen vähän.

Sen lisäksi, että itse opetan ja nautin muiden opetuksesta, pyrin myös opetuksessa ja politiikassa puoltamaan julkisia eli kunnallisia palveluita. Nykyisin tosin huonolla menestyksellä.

Kuluttajan valinnat ovat valitettavan vähissä esimerkiksi kelvollisen rakentamisen osalta. Parhaillaan puhutaan koulujen ja yliopistojen sisäilmaongelmista. Niiden syynä on mielestäni julkisen rakentamisen(kin) antaminen grynderien käsiin. Usein rakennukset joudutaan korjaamaan saman tien, ja korjauksia tehdään uudestaan ja uudestaan. Se on törkeää tuhlausta. Talojen rakentamiseen tarvittaisiin enemmän asiantuntevaa, julkista kontrollia. Kontrollin puute koskee myös esimerkiksi Talvivaaran kaivosta. Puute ulottuu lisäksi suuriin rakennushankkeisiin, teihin ja kaupunkien ulkopuolella oleviin kauppakeskuksiin.

Näitä palveluita kuluttajat silti käyttävät, pystymättä itse tekemään valintoja.

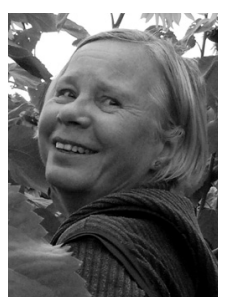

Leena Eräsaari

yhteiskuntatieteiden tohtori sosiaalityön professori Jyväskylän yliopisto 